\title{
Public Use of Rare Archives and Valuable Library Documents
}

\author{
JOZEF HANUS, PH.D. ING. \\ Faculty of Chemical and Food Technology, Slovak University of Technology, Radlinského 9, 81237 Bratis- \\ lava, Slovak Republic \\ e-mail: jozef.hanus@stuba.sk
}

EMILIA HANUSOVÁ, ING.

University Library Bratislava, Michalská 1, 81417 Bratislava, Slovak Republic

e-mail:emilia.hanusova@ulib.sk

Public Use of Rare Archives and Valuable Library Documents

\section{ABSTRACT}

Digital conversion of cultural artefacts of all kinds has advanced rapidly in the past few years. People can explore many of the most known and popular artworks, artefacts, books, videos and sounds, etc. from all over the world via the Internet from the comfort of their living rooms. Despite this fact the exhibition of rare archival and valuable library documents still remains one of the most popular and significant way of presentation of this cultural heritage type to the broad public. On the other hand the exhibitions represent also the most possible cause and risk of their physical degradation if the climatic, handling and safety conditions during the exhibition are not properly adjusted and kept. Also the unsuitable conditions of their transport to and from the place of exhibition raise possibilities for their physical damage. The paper presents the main causes of possible damage and degradation of documents as well as some preservation precautions applied in order to minimise risk of their damage.

Key words: rare documents, public use, exhibition, document damage/degradation, preservation, safety, security, standards

Uso pubblico degli archivi rari e di documenti librari di valore

SINTESI

La conversione digitale dei prodotti culturali è avanzata rapidamente negli ultimi anni. Si possono esplorare molti dei più noti e popolari oggetti d'arte, manufatti, libri, video e registrazioni sonore, ecc.. provenienti da tutto il mondo tramite internet standosene confortevolmente nel proprio salotto. Nonostante ciò, le mostre di materiale archivistico raro e di documenti di valore rimangono ancora una delle più popolari e significative vie di presentazione di questo patrimonio culturale al grande pubblico. D'altra parte le mostre rappresentano anche una delle possibili cause e rischi del loro degrado fisico se le condizioni climatiche, di maneggio e di sicurezza durante la mostra non sono fissate e gestite correttamente. Anche condizioni inadatte per il loro trasporto verso e da il luogo della mostra aumentano le possibilità di un loro danneggiamento. L'articolo presenta le principali cause di possibili danni e degrado dei documenti, così come alcune precauzioni per la conservazione applicate in modo da minimizzare il rischio di danneggiamento.

Parole chiave: documenti rari, utilizzo pubblico, mostre, danneggiamento del documento, conservazione, sicurezza, standard

Javna uporaba redkega arhivskega gradiva in dragocenih knjižničnih dokumentov

\section{IZVLEČEK}

Digitalna pretvorbi kulturnih artefaktov vseh vrst je v zadnjih nekaj letih hitro napredovala. Ljudje lahko raziskujejo mnoge izmed najbolj znanih in priljubljenih umetniških del, predmetov, knjig, video posnetkov in zvokov, itd. iz vsega sveta preko interneta iz udobja svoje dnevne sobe. Kljub temu pa so razstave redkega arhi- 
vskega gradiva in dragocenih knjižničnih dokumentov še vedno ena izmed najbolj priljubljenih in najpogostejših načinov predstavitve tega tipa kulturne dediščine v širši javnosti. Po drugi strani pa razstave v primeru nezagotavljanja ustreznih klimatskih pogojev ter neustreznega ravnanje in varnostnih pogojev, predstavljajo tudi najbolj možen vzrok in tveganje za fizično propadanje kulturne dediščine. Tudi neustrezni pogoji za njihov prevoz $\mathrm{v}$ in iz kraja razstave, povečujejo možnosti za njihovo fizično poškodovanje. $\mathrm{V}$ prispevku so predstavljeni poglavitni vzroki za morebitne poškodbe in degradacijo dokumentov, kot tudi nekateri varnostni ukrepi za ohranitev, ki se uporabljajo z namenom zmanjšanja tveganja za poškodbe.

Ključne besede: redki dokumenti, javna uporaba, razstava, poškodba gradiva, razkroj gradiva, hramba, varnost, standardi

\section{Verejné využívanie vzácnych archívnych aknižničných dokumentov}

\section{ABSTRAKT}

Digitálna konverzia kultúrnych artefaktov všetkého druhu postupuje v posledných rokoch velmi rýchlo. Ludia si môžu prezriet mnohé z najznámejších a najpopulárnejších umeleckých diel, artefaktov, dokumentov, kníh, obrazov, zvukových nahrávok, filmov, atd'. z celého sveta cez Internet z pohodlia svojej obývačky. Napriek tejto skutočnosti výstava vzácnych archívnych a knižničných dokumentov a iných diel umeleckých či historických artefaktov zostáva jedným z najpopulárnejších a najvýznamnejších spôsobov prezentácie tohto typu kultúrneho dedičstva širokej verejnosti. Na druhej strane predstavuje však aj jednu z najpravdepodobnejších možností, príčin a rizík ich fyzickej degradácii, ak klimatické a bezpečnostné podmienky v priebehu výstavy či manipulácia $s$ vystavovanými dielami nesplňajú požadované kritériá. Tiež nevhodné podmienky ich prepravy do a z miesta výstavy zvyšujú možnosti ich fyzického poškodenia. Príspevok predstavuje hlavné príčiny možného poškodenia a degradácii dokumentov, rovnako ako niektoré opatrenia preventívnej ochrany, aby sa minimalizovalo riziko ich poškodenia.

\section{Introduction}

A massive introduction of information technology in every field of human activities leads to a transition from industrial to information society. Reality of these previously only theoretical and philosophical considerations is presented nowadays by Internet technology and services. Internet and connected technology create an infrastructure for a global information exchange and enable creation and utilisation of information sources wherever it is and to anybody who has an access to Internet.

Digital conversion of cultural artefacts of all kinds has advanced rapidly in the past few years. It promises to continue to expand its reach and improve its capacities. Digitization has proven to be possible for nearly every format and medium presently held by archives, libraries, museums, galleries - from manuscripts to maps, and moving images to musical recordings. Digitization is no doubt the issue that more than anything else fascinates public record managers in many memory institutions. The possibilities seem limitless, the advantages are obvious and "archives, libraries, museums and galleries without walls" are seemed to become very close future.

"Welcome, culture lover! Whether you came here for inspiration, to work on your research, looking for your next coffee mug design or just to snoop around, we hope you will find what you need somewhere amongst the millions of objects we host here". "Explore 53,042,382 artworks, artefacts, books, videos and sounds from across Europe" (Europeana 2016 (see picture 1). 


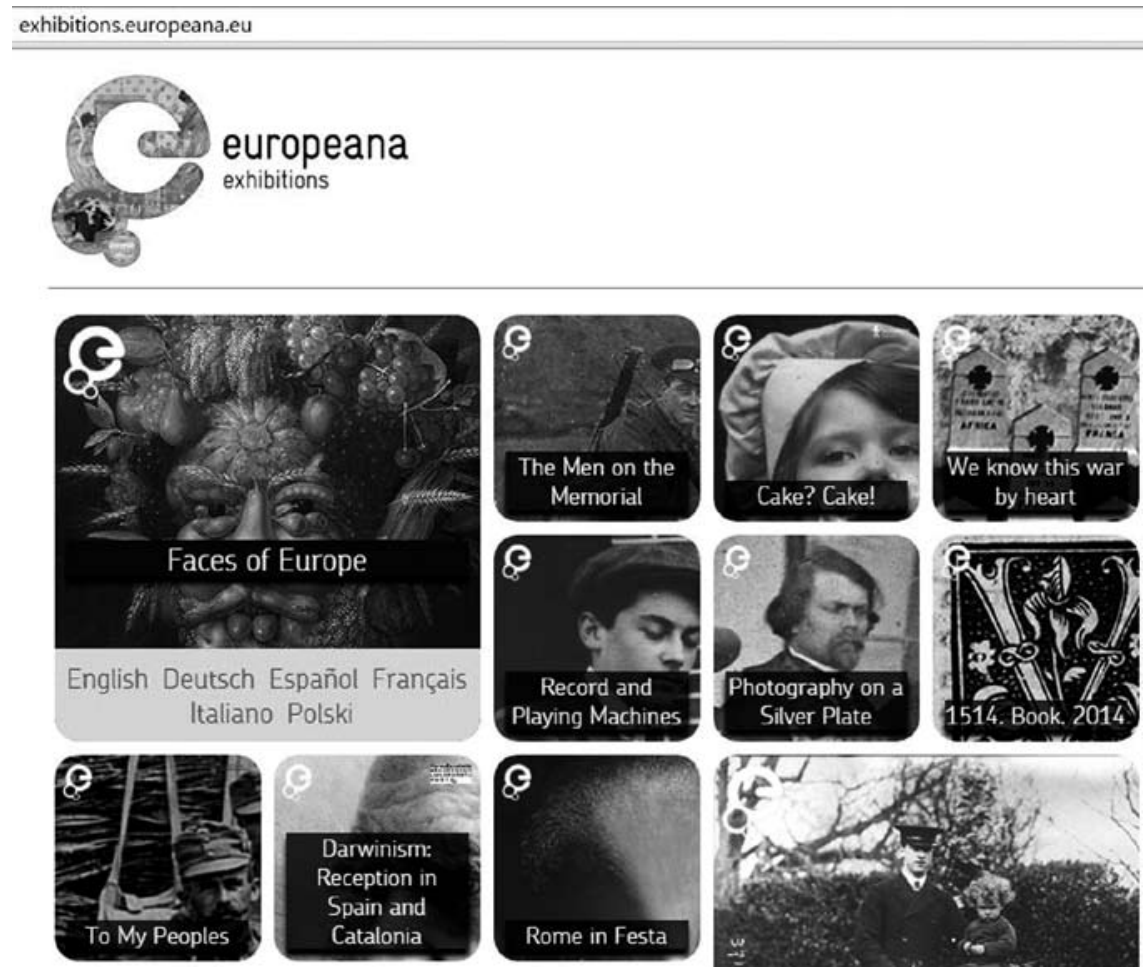

Image 1: Website of Europeana

People can explore many of the most known and popular artworks, artefacts, books, videos and sounds, etc. from across the Europe or all over the world via the Internet from the comfort of their living rooms.

Many national (e.g., University Library Bratislava 2016 (see picture 2), Slovakiana 2016 (see picture 3)) and international cultural institutions, organizations and consortiums (e.g. ICARUS 2016, (see picture 4)) provide valuable information and documents via their web sites or some portals.

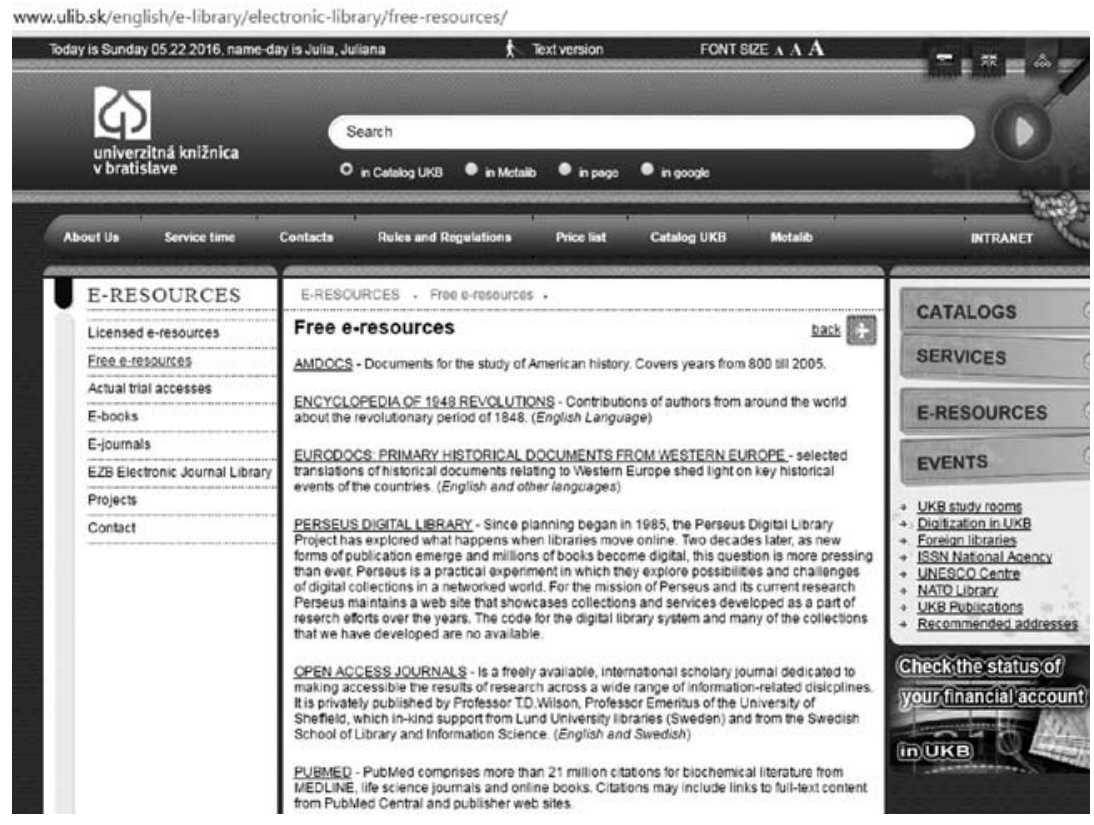

Image 2: Website of the University Library in Bratislava 


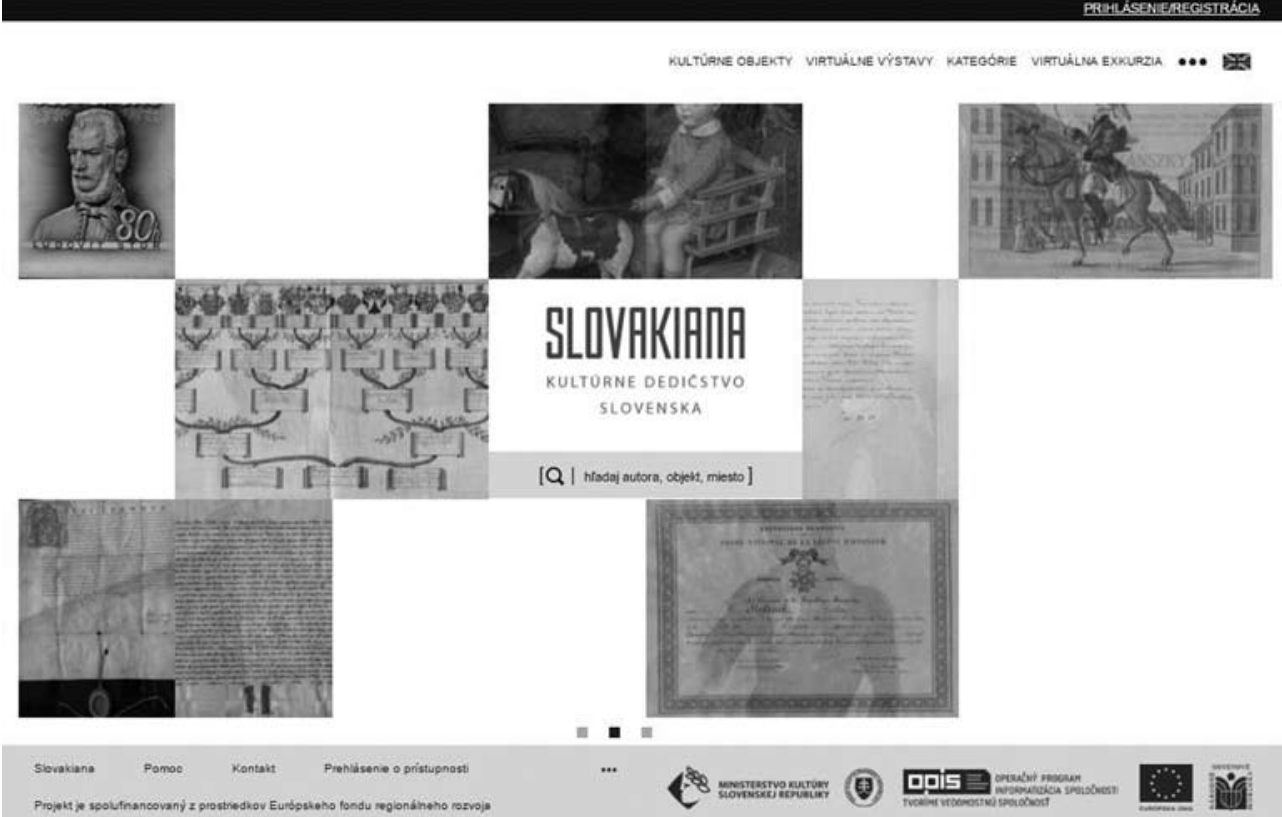

Image 3: Website of Slovakiana
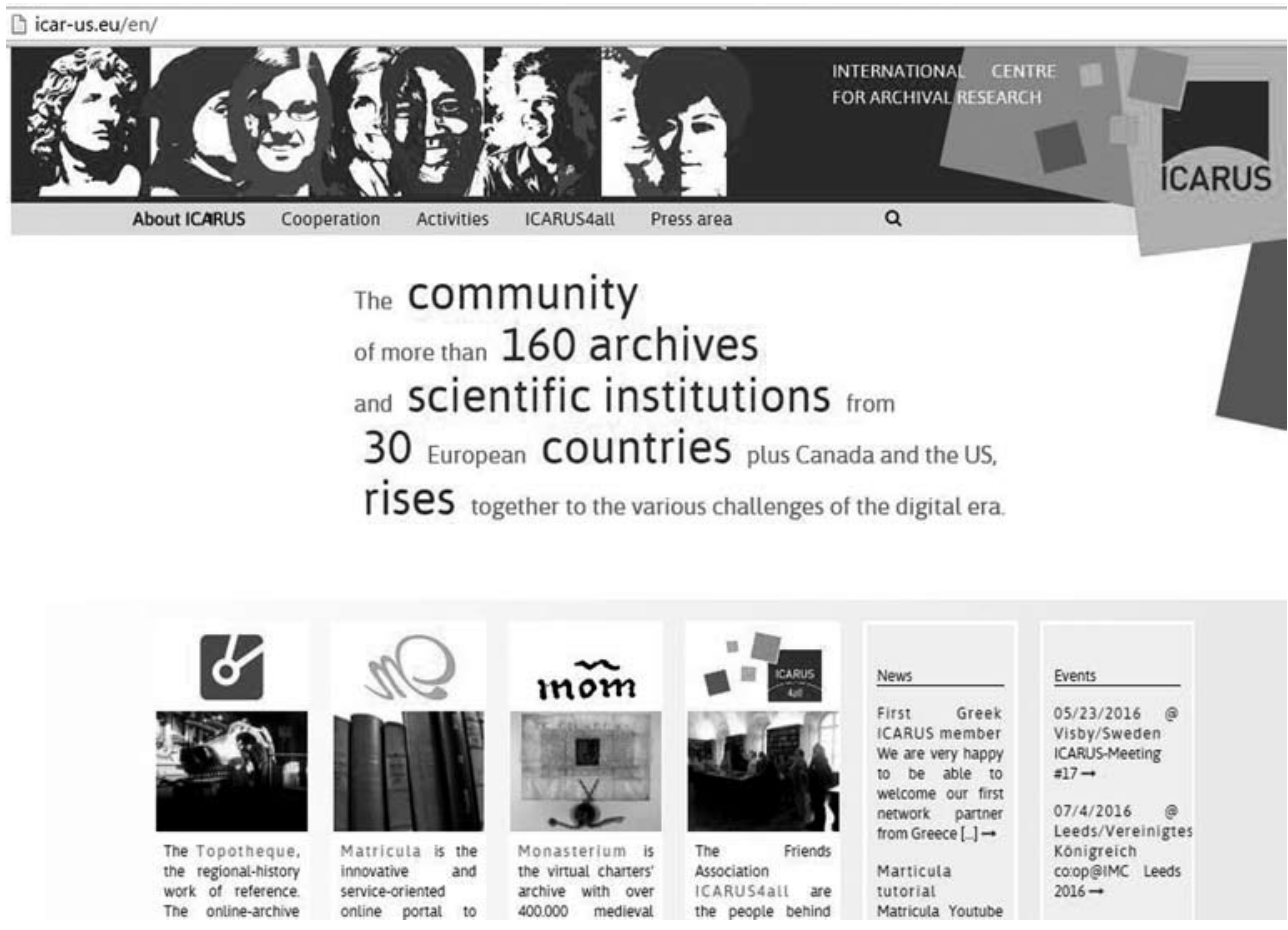

Image 4: Website of ICARUS

Despite this fact the exhibition of rare archival and valuable library documents still remains one of the most popular and significant way of presentation of this cultural heritage type to the broad public.

Exhibitions should be educational and enjoyable and above all safe for exhibited documents. Exhibiting works of art or artefacts, especially the unique, the rare, and the wonderful, is an important part of the educational mission of many institutions. It is also an effective way of attracting the atten- 
tion and support of the public. The principal aim of all memory institutions is to acquire, professionally process and make archival documents accessible for public purposes on one hand and to preserve and save them at the same time in order to keep them for an indefinite time period. Although exhibition can complicate or even compromise preservation efforts, it is nearly impossible to avoid exhibiting original documents. Therefore it is inevitable to take and apply some measures and precautions to minimise risk or their damage.

\section{Legislative measures}

In order to minimize the risk of valuable documents damage in exhibitions the complex of measures and provisions should be taken and applied into account. The first step in the process should be legislative measures. Of course, they can differ in different countries in their range, scope and level of significance. In principle, the legislative measures found in different countries can be divided into three levels:

- provisions (acts, laws, etc.) usually concerning archives which mention in general also necessity of preservation archival documents during exhibition;

- provisions (regulations, ordinance, recommendations, etc.) concerning archives, storage or preservation of archival documents in which also questions and problems connected with their exhibiting are dealt with in more detailed way, with specification of safety, climatic and other conditions (loan, contract, etc.);

- special standards concerning storage and/or exhibiting archival documents and library materials specifying problems and providing solutions, patterns for records about physical state of document before and after exhibition, conditions of loan, transport, climatic conditions, display cases, etc.

There are also countries reporting no regulations concerning the subject (Hanus 2004).

\section{Climatic and light conditions}

Most of archival and library documents are made from organic raw materials, largely plant fibres and animal skin. This makes them (especially paper) prone to decay and vulnerable by the environmental conditions in which they are kept. Ageing is an irreversible process that deteriorates mechani$\mathrm{cal}$, physical, chemical and optical properties of paper or materials of which the cultural artefacts are made and is significantly influenced by internal and external degradation factors. The most important internal factors are given by the nature of materials which the documents are made of or they are established during manufacture of these materials. The external factors are related to deleterious influence of the storage conditions - such as temperature and humidity, light, air pollutants, microbial attack, atmospheric oxidation, etc. (Hanus 1987).

Light is one of degradation factors which deleterious effect is very often underestimated. Especially paper containing high portion of groundwood, produced since the 2 nd half of the 19 th century is sensitive to its influence and is expected to have a short life-time. Nowadays there is a good deal of information about the influence of light on the ageing of groundwood papers (Heitner 1993, Havermans 1997, Bukovsky 2000). Light induced oxidation degradation reactions are typical reactions of lignin, characteristically manifest as the yellowing of paper, producing a large amount of law molecular degradation products, a significantly increase of acidity and intensely reduced strength during 30 days of daylight ageing, even with significantly reduced portion of UV radiation.

The (Act No. 395/2002) of the National Council of the Slovak Republic on Archives and Registries provides general provisions also for preservation of archival documents in Slovak Republic. The (Regulation no. 628/2002) contains a special part devoted to conditions under which archival documents can be used for exhibition, required safety precautions, climatic (temperature $16-20^{\circ} \mathrm{C}, 45-55 \% \mathrm{RH}$ ) and light conditions (maximum $50 \mathrm{~lx}, 18000$ lx.h per year for documents containing inks, dyes and light-sensitive pigments).

On the basis of an extensive study of light influence on archival documents Principles of exhibiting archival documents were published (Ďrovič 2003). Besides general principles concerning docu- 
ments exhibiting (approval, loan conditions, physical condition document passport, document exhibiting protocol etc.) it specifies three categories of materials according to their sensitivity to light applying the (British Standard 1006: 2001) and (ISO 105: 1994) (1st category - the most sensitive materials, 2nd - medium, 3rd - durable) and maximal year exposure and illumination intensity (1st category - 12000 lx.h and 50 lx, 2nd -42000 lx.h and 75 lx, 3rd - 54000 lx.h and 100 lx). Climatic conditions in exhibition rooms should be within the range of $15-20^{\circ} \mathrm{C}\left( \pm 2^{\circ} \mathrm{C}\right)$ and $50 \pm 5 \%$ relative humidity. It also recommends decreasing acceptable part of UV-radiation from 75 microW/lumen to $10 \mu \mathrm{W} / \mathrm{lm}$.

(ISO 11799: 2003) covers also exhibitions for which generally the same requirements regarding room climate, security, etc. as for document repositories are applied. Exhibitions put documents at increased risk, and shall therefore be restricted to a minimum. Items should not be permanently on exhibition. Being on exhibition means that the surface of a document is exposed to extensive periods of light. Furthermore, the damage done by light to a document is cumulative. Consequently, both the intensity and the duration of light exposure on a document on exhibition shall be reduced to a minimum. This is especially necessary for the most sensitive items such as modern writing inks, acidic groundwood paper, colour photographs, coloured prints and drawings, etc. A light level of 50 lux on the displayed document is sufficient for viewing if ambient light levels are lower and sufficient time is allowed for the viewer's eyes to adjust to the lower light level. Neither incandescent light, nor any other heat-generating light source shall be placed inside or close to a display case. For documents required repeatedly for exhibition a facsimile substitute should be provided.

The most comprehensive of reviewed regulations is the French standard „Preservation requirements for exhibiting graphic and photographic materials" (Norme NF Z 40-010: 2002). This standard describes a set of requirements aiming at assuring the best conditions for preservation of graphic and photographic documents - kept in libraries, archives and museums - in the process of their exhibiting. It is destined for those who are responsible for collections and fonds in these institutions in order to provide the tools, ways and all possible precautions to prevent as much as possible the factors of documents degradation during exhibition. It contains the requirements concerning the administrative measures for loans, insurance, manipulation, treatment, preparation, transport before and after the exhibition.

It is useful for organisers of exhibitions, owners and borrowers, preparation of exhibitions (production of mobiliari, contract of transport, loan and insurance contracts, etc.) and it serves as a base for consultation among the different participant involved in exhibition (conservators, custodians, set designers, exhibition commissars, restorers, etc.).

The administrative part of the standard covers general questions - validity of standard for both internal and external exhibitions, procedure of the loan (giving an example of a very detail required records in Annexe A) and conditions of insurance. Annex B provides a model exhibition contract.

Management of document before and after the exhibition recommends necessary treatment by the owner, packing (materials), transport conditions and the treatment by the borrower (Annex C requires information concerning the state and conditions of documents and used treatment).

Chapter Exhibition conditions is very comprehensive and specifies place and equipment, showcases and support materials for exhibited documents (Annexe D) as well as principles of their installation, mounting and de-mounting. Temperature-humidity conditions in general are applied in accordance with AFNOR prNF ISO 11799. The classification of materials according to their sensitivity to light (heavily sensitive, very heavily sensitive and extremely sensitive) and maximal exposure limits (84 000 lx.h/year, 42000 lx.h/year and 12500 lx.h/year) with elimination of UV-rays, visible light control and maximal reduction of infra-red radiation $(30 \mathrm{~W} / \mathrm{m} 2)$ create very important part of the standard. The standard also requires specification of total light quantity received by document during exhibition and some minimal necessary information and data according to enclosed pattern.

Detail information concerning specific conditions of temperature, relative humidity, light and other parameters concerning the problems of exhibiting of documents in different countries are provided in work (Hanus 2004). 


\section{References}

Act (2002). Zákon č. 395/2002 Z.z. zo 17. mája 2002 o archivoch a registratúrach a o doplneni niektorých zákonov (The Act no. 395/2002 on Archives and Registries and on the Amendments of Certain Acts).

British Standard 1006: (2001). Blue Wool Scale British Blue Wool Standard.

Bukovský, V. (2000). The natural ageing of paper after exposure to daylight. Restaurator 21, pp. 229-237.

Durovič, M. (2003). Zásady vystavováni archiválii ve Státním ústředním archivu v Praze (Principles of exhibiting archival documents at the State Central Archives in Prague). Archivní časopis 1, ročník 53, pp. 37-50.

Europeana (2016). Available at: http://www.europeana.eu/portal/ (accssed on May 22, 2016).

Hanus, J. (1987). Štúdium starnutia papiera z hladiska ochrany archivnych dokumentov. Kandidátska dizertačná práca. (Study of paper ageing from the point of preservation of archives. PhD thesis). Chemical-Technological Faculty, Slovak Technical University Bratislava, 1987.

Hanus, J. (2004). Exhibition of Archival Documents and Legislation (A Survey of International Legislative Provisions). In: Proceedings of International symposium „Exhibiting Archival and Library Materials and Work of Art on Paper: Standards in Preservation“, Edited by Jederet Vodopivec. Ljubljana, Slovenia, June 5-6, 2003. ISBN 961-6137-76-X. National and University Library Ljubljana, 2004, pp. 195-204.

Havermans, J. B. G. A., Dufour, J. (1997). Photo oxidation of paper documents. A Literature Review. Restaurator 18, pp. 103-114.

Heitner, C, Scaiano, J. C. (1993). Photochemistry of lignocellulosic materials. ACS Symposium Series 531, Washington, D.C., Am. Chem. Soc.

ISO 105-B02: (1994). Textils. Tests for colour fastness. Color fastness to artificial light. Xenon arc fading lamp test.

ISO 11799: (2003). Information and documentation - Document storage requirements for archive and library materials.

Norme NF Z 40-010: (2002). Prescriptions de conservation des documents graphiques et photographiques dans le cadre d'une exposition. AFNOR Juin 2002.

Slovakiana (2016). https://www.slovakiana.sk/ (accessed on May 22, 2016).

University Library Bratislava (2016). http://www.ulib.sk/english/e-library/electronic-library/free-resources/ (accessed on May 22, 2016).

Regulation (2002). Vyhláška Ministerstva vnútra Slovenskej republiky č. 628/2002 Z.z. z 29. októbra 2002, ktorou sa vykonávajú niektoré ustanovenia zákona o archivoch a registratúrach a o doplneni niektorých zákonov (The Regulation no. 628 of the Ministry of Interior of the Slovak Republic from 29 October 2002 by which some provisions of the Act on Archives and Registries are executed).

\section{SUMMARY}

Digital conversion of cultural artefacts of all kinds has advanced rapidly in the past few years. People can explore many of the most known and popular artworks, artefacts, books, videos and sounds, etc. from all over the world via the Internet from the comfort of their living rooms. Despite this fact the exhibition of rare archival and valuable library documents still remains one of the most popular and significant way of presentation of this cultural heritage type to the broad public. On the other hand the exhibitions represent also one the most possible cause and risk of their physical degradation if the climatic, handling and safety conditions during the exhibition are not properly adjusted and kept. Also the unsuitable conditions of their transport to and from the place of exhibition raise possibilities for their physical damage. In order to minimize the risk of valuable documents damage in exhibitions the complex of measures and provisions should be taken and applied into account. The first step in the process should be legislative measures. Of course, they can differ in different countries in their range, scope and level of significance. The quality of legislative measures concerning exhibiting archival documents varies in different countries from general recommendations to very specific and detailed standards. From preservation point of view they usually contain two parts: the first one covers general provisions and administration requirements concerning exhibition activities - permission, the state of documents for exhibition, loans, contract, insurance, transport, safety precautions, etc. These provisions are more or less very similar in all regulations. The second part usually covers technical conditions and requirements - the most emphasised of them are climatic conditions, illumination and display cases. Temperature range $16-20^{\circ} \mathrm{C}$ and $45-55 \%$ relative humidity are most frequently recommended as well as maximal illumination intensity of $50 \mathrm{~lx}$. The most com- 
Jozef HANUS - Emília HANUSOVÁ: Public Use of Rare Archives and Valuable Library Documents, 225-232

prehensive of reviewed regulations in this field is the French standard „Preservation requirements for exhibiting graphic and photographic materials" (Norme NFZ 40-010: 2002).

Typology: 1.04 Professional Article

Submitting date: 01.02 .2016

Acceptance date: 20.02 .2016 